\title{
Transparansi Penggunaan Dana Desa di Nagari Talaok Kecamatan Bayang Kabupaten Pesisir Selatan
}

\author{
Pina Miranda, Akmal \\ Program Studi Pendidikan Pancasila dan Kewarganegaraan \\ Universitas Negeri Padang \\ E-mail: vinamiranda685@gmail.com
}

\section{ABSTRAK}

Transparansi penggunaan dana desa merupakan pertanggungjawaban pemerintah nagari kepada masyarakat sesuai dengan aturan yang berlaku. Namun, pemerintahan Nagari Talaok kurang memberikan akses informasi transparansi dana desa kepada masyarakat. Artikel ini bertujuan untuk mengelaborasi transparansi penggunaan dana desa di Nagari Talaok dan mengidentifikasi kendala-kendala yang dialami pemerintahan Nagari Talaok dalam transparansi penggunaan anggaran dana desa tersebut. Penelitian ini adalah penelitian deskriptif kualitatif dengan 9 orang informan secara purposive sampling. Data dikumpulkan melalui wawancara, observasi, dan dokumentasi. Hasil penelitian menunjukan bahwa transparansi penggunaan dana desa di Nagari Talaok sudah sesuai dengan indikatorindikator transparansi yaitu kesediaan dan aksesibilitas dokumen, kejelasan dan kelengkapan informasi, keterbukaan proses, dan kerangka regulasi yang menjamin transparansi. Pelaksanaan pertanggungjawaban dana desa secara teknis maupun administrasi sudah baik namun ada beberapa kendala-kendala yang dialami pemerintah Nagari Talaok dalam transparansi penggunaan dana desa yaitu dalam musyawarah nagari dukungan masyarakat beragam, aparatur nagari dalam menjalankan fungsinya berjalan dengan baik tetapi kurang optimal. Dapat disimpulkan bahwa transparansi penggunaan dana desa di Nagari Talaok sudah sesuai dengan indikator namun dalam musyawarah nagari dukungan masyarakat beragam serta aparatur nagari menjalankan fungsinya belum optimal.

Kata Kunci: transparansi, dana desa, Nagari Talaok

\section{ABSTRACT}

Transparency in the use of village funds is the responsibility of the nagari government to the community in accordance with applicable regulations. However, Nagari Talaok government lacked access to transparency information on village funds to the community. This article aims to elaborate the transparency of the use of village funds in Nagari Talaok and identify the constraints experienced by the Nagari Talaok government in the transparency of the use of the village fund budget. This research is a qualitative descriptive study with 9 informants. Data collected through interviews, observations, and documentation. The results showed that transparency in the use of village funds in Nagari Talaok was in accordance with transparency indicators, namely the availability and accessibility of documents, clarity and completeness of information, process transparency, 
and regulatory framework that guarantees transparency. The implementation of accountability of village funds technically and administratively is good, but there are some obstacles experienced by the Nagari Talaok government in transparency of the use of village funds, namely in the nagari deliberations of diverse community support, the nagari apparatus in carrying out their functions are running well but not optimal. It can be concluded that the transparency of the use of village funds in Nagari Talaok is in accordance with the indicators but in the village consultation the diverse community support as well as the village apparatus performing their functions is not optimal yet.

Keywords : transparency, village funds, Nagari Talaok

This work is licensed under the Creative Commons Attribution-ShareAlike 4.0 International License. (2019 by author.

\section{PENDAHULUAN}

Desa merupakan pemerintahan terendah yang memiliki kewenangan dalam penyelenggaraan pemerintahan administratif dan pengelolaan keuangan desa. Sumber keuangan desa dalam Undang-Undang Nomor 06 Tahun 2014 pasal 72 terdiri dari pertama pendapatan asli daerah yang meliputi hasil usaha, hasil asset, swadaya, partisipasi, gotong royong, dan lain-lain pendapatan asli desa. Kedua dari APBN, hasil pajak daerah atau retribusi daerah, alokasi Dana Desa yang merupakan bagian dari dana perimbangan, yang diterima Kabupaten/Kota, bantuan keuangan dari APBD provinsi dan APBD Kabupaten/Kota, hibah dan sumbangan yang tidak mengikat dari pihak ketiga, dan lain-lain pendapatan desa yang sah.

Terkait dengan besarnya anggaran yang diterima oleh pemerintahan desa, maka pemerintah pusat mengeluarkan regulasi mengenai pedoman pengelolaan keuangan pemerintah desa melalui Peraturan Menteri Dalam Negeri Nomor 113 tahun 2014 Tentang Pengelolaan Keuangan Desa Pasal 1 ayat (6) yang menjelaskan bahwa pengelolaan keuangan desa merupakan seluruh rangkaian kegiatan yang dimulai dari tahap perencanaan, pelaksanaan, penatausahaan, pelaporan hingga pertanggung jawaban yang dilaksanakan dalam satu tahun anggaran 1 Januari sampai dengan 31 Desember. Pengelolaan keuangan desa dilaksanakan berdasarkan azas transparan, akuntabel, partisipatif, tertib dan disiplin anggaran.

Pemerintahan desa harus bisa menerapkan prinsip transparansi dalam pengelolaan keuangan desa, dimana semua akhir kegiatan penyelenggaraan pemerintahan desa harus dapat dipertanggung jawabkan kepada masyarakat desa sesuai dengan ketentuan Undang-Undang. Bentuk pertanggung jawaban yang bisa dilakukan aparatur pemerintahan desa kepada masyarakat yaitu menyusun kerangka regulasi yang menjamin wujud transparansi pemerintahan desa kepada masyarakat. Membuat laporan dokumen kegiatan pengelolaan keuangan desa secara jelas dan lengkap. Laporan kegiatan yang telah disusun wajib di informasikan kepada masyarakat secara terbuka. 
Provinsi Sumatera Barat merupakan bagian dari wilayah Negara Kesatuan Republik Indonesia yang memiliki 928 desa dari 14 daerah Kabupaten/Kota. Istilah desa di provinsi Sumatera Barat disebut dengan nama nagari. Dalam Perda Provinsi Sumatera Barat Nomor 2 Tahun 2007 Tentang Pokok-Pokok Pemerintahan Nagari pasal 1 ayat 7 dinyatakan bahwa nagari adalah kesatuan masyarakat hukum adat yang memiliki batas-batas wilayah tertentu dan berwenang untuk mengatur dan mengurus kepentingan masyarakat setempat berdasarkan filosofi adat Minangkabau (Adat Basandi Syarak, Syarak Basandi Kitabullah) dan atau berdasarkan asal usul dan adat istiadat setempat dalam wilayah provinsi Sumatera Barat.

$$
\text { Nagari Talaok sebagai }
$$
pemerintahan terendah memiliki kewenangan untuk menjalankan roda pemerintahan sebagaimana nagari atau desa lainnya di seluruh wilayah Indonesia. Berdasarkan pengamatan dan informasi yang diperoleh peneliti tentang pengelolaan keuangan di Nagari Talaok masih banyak permasalahan yang terjadi akibat kesalahan dalam pengelolaan keuangan Nagari. Kesalahan itu mungkin saja disebabkan oleh rendahnya pengetahuan dan pemahaman aparatur pemerintahan Nagari Talaok terhadap regulasi yang diterbitkan oleh pemerintah. Selain itu, peneliti juga melihat adanya indikasi yang menyatakan sikap pemerintahan Nagari Talaok menutup akses informasi bagi masyarakat untuk mengetahui laporan pertangung jawaban pemerintahan Nagari dan laporan penggunaan keuangan Nagari. Padahal masyarakat berhak mengetahui pos penggunaan anggaran dana tersebut melalui laporan kinerja pemerintahan nagari.

Upaya mengukur tingkat transparansi keuangan Negara yang dikelola oleh pemerintah dapat dilakukan melalui berbagai cara. Menurut Kristianten (2006:73) langkah utama yang dapat dilakukan dengan melihat ketersedian aksesibilitas dokumen untuk diketahui oleh masyarakat. Ketersedian aksesibilitas dokumen merangkum seluruh laporan kegiatan yang telah dilakukan dalam satu tahun anggaran. Dokumen tersebut biasanya tersusun dalam bentuk laporan tertulis yang telah disusun oleh pemerintahan Nagari sebagai pihak eksekutor yang menjalankan roda pemerintahan dan agenda pembangunan. Di Nagari Talaok laporan kinerja penggunaan anggaran tetap dibuat, namun tidak dipublikasikan kepada masyarakat secara terbuka. Indikasi inilah yang menimbulkan kecurigaan masyarakat terhadap wali nagari sebagai pemimpin.

Terjadinya berbagai persoalan di atas dan juga dialami oleh Nagari Talaok dalam penggunaan anggaran dana desa sehingga menimbulkan berbagai macam kecurigaan oleh masyarakat. Namun disisi lain laporan yang telah disusun oleh pemerintahan Nagari Talaok dapat diterima oleh Dinas Pemberdayaan Masyarakat Desa Kabupaten Pesisir Selatan secara sah. Menanggapi hal ini, maka muncul rasa keingintahuan peneliti untuk melakukan penelitian lebih dalam tentang bagaimana upaya yang dilakukan pemerintahan Nagari Talaok dalam mewujudkan Transparansi penggunaan Anggaran Dana Desa dan kendala-kendala yang 
dialami pemerintahan Nagari Talaok dalam menggunakan anggara Dana Desa.

Berdasarkan identifikasi masalah tersebut, maka pembatasan masalah dalam penelitian ini adalah terhadap transparansi penggunaan dana Desa Nagari Talaok Kecamatan Bayang Kabupaten Pesisir Selatan. Rumusan masalah dalam penelitian ini yaitu transparansi penggunaan dana desa di Nagari Talaok Kecamatan Bayang Pesisir Selatan. Juga mengenai kendala-kendala yang dialami pemerintahan Nagari Talaok dalam transparansi penggunaan anggaran dana desa di Nagari Talaok Kecamatan Bayang Pesisir Selatan.

Setiap penelitian tentunya pasti memiliki tujuan yang akan dicapai. Dari rumusan masalah yang telah dikemukakan diatas maka tujuan penelitian ini adalah untuk mendeskripsikan transparansi penggunaan dana desa dan untuk mengidentifikasi kendala-kendala yang dialami pemerintahan Nagari Talaok dalam transparansi penggunaan anggaran dana desa di Nagari Talaok Kecamatan Bayang Pesisir Selatan.

Secara teoritis penelitian ini dapat memperkaya khasanah keilmuan di bidang sistem pemerintahan daerah yang berkaitan dengan tata kelola pemerintahan dan secara praktis dapat menjadi bahan masukan dalam pengelolaan dan pelaporan keuangan bagi pemerintah seperti pemerintahan nagari/desa, pemerintahan kabupaten/kota dan pemerintahan provinsi.

\section{METODE PENELITIAN}

Penelitian ini menggunakan pendekatan deskriptif kualitatif. Penelitian ini dilakukan di Nagari Talaok Kecamatan Bayang Kabupaten Pesisir Selatan. Pemilihan informan pada penelitian ini menggunakan teknik pusposive sampling. Teknik Pengumpulan Data menggunakan teknik wawancara dan Dokumentasi. Teknik trianggulasi data yang dipakai pada penelitian ini adalah triangulasi sumber yaitu membandingkan dan mengecek balik derajat kepercayaan suatu informasi yang diperoleh melalui waktu dan alat yang berbeda. Analisis data dalam penelitian kualitatif dilakukan pada saat pengumpulan data berlangsung dan setelah selesai pengumpulan data dalam periode tertentu. Pada saat wawancara, peneliti sudah melakukan analisis terhadap yang diwawancarai.

\section{HASIL DAN PEMBAHASAN}

Transparansi Penggunaan Dana Desa di Nagari Talaok Kecamatan Bayang $\underline{\text { Pesisir Selatan }}$

Transparan adalah prinsip keterbukaan yang memungkinkan masyarakat untuk mengetahui dan mendapatkan akses informasi seluasluasnya tentang keuangan daerah (Permendagri No. 113 Tahun 2014). Sedangkan menurut Krina (2003), transparansi adalah prinsip yang menjamin akses atau kebebasan bagi setiap orang untuk memperoleh informasi tentang penyelenggaraan pemerintahan, yakni informasi tentang kebijakan, proses pembuatan dan pelaksanaannya, serta hasil-hasil yang dicapai (Krina, 2003). 
Prinsip transparansi di Nagari Talaok terlihat dari adanya partisipasi masyarakat dan BAMUS dalam musyawarah nagari untuk membahas perencanaan penggunaan dana desa meskipun masyarakat yang berpartisipasi masih belum lengkap, setidaknya pemerintah Nagari Talaok sudah berupaya untuk mewujudkan prinsip transparansi pada tahap perencanaan pengelolaan alokasi dana desa di Nagari Talaok.

Dari hasil wawancara dengan informan dapat disimpulkan bahwa pemerintah Nagari Talaok telah mewujudkan prinsip transparansi dengan baik. Hal ini dapat dilihat pada tahap pelaksanaan, dimana pemerintah Nagari Talaok menyarankan warga untuk membentuk program kerja, dengan tujuan agar tercapainya prinsip transparansi. Kemudian dalam proses pertanggungjawaban bentuk transparansinya dapat dilihat dari baliho dan papan informasi tentang pengelolaan Alokasi Dana Desa yang selalu terpampang di depan kantor Wali Nagari Talaok sehingga masyarakat dapat mengetahui secara rinci mengenai pengelolaan dan penggunaan ADD di Nagari Talaok. Hal itu dapat kita lihat pada gambar berikut:

\section{Gambar 1}

Baliho APB Nagari Talaok Kec. Bayang, Kab Pesisir Selatan

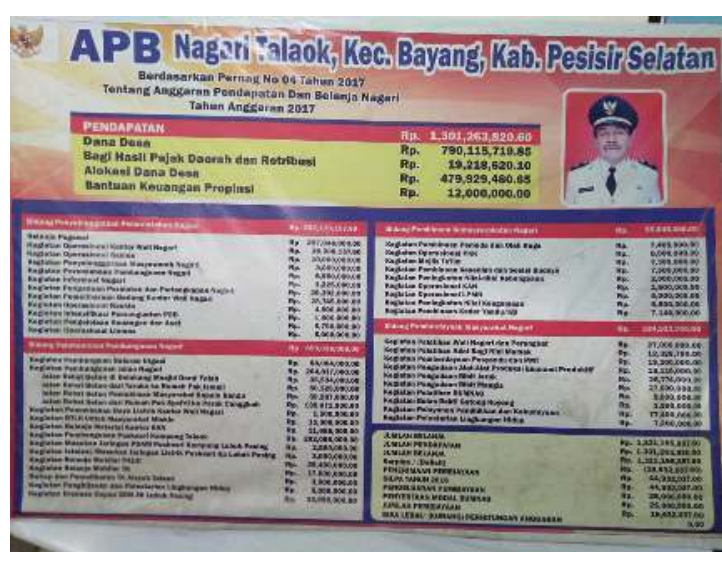

Transparansi berarti pemerintah nagari mengelola keuangan secara terbuka. Sebab hal itu merupakan barang publik yang harus diketahui oleh masyarakat. Pemerintah nagari wajib menyampaikan informasi secara terbuka, jelas dan lengkap kepada masyarakat. Informasi yang jelas dan lengkap mengenai pengelolaan dana desa akan meningkatkan kepercayaan dan penghormatan masyarakat kepada pemerintah nagari.

Dari hasil penelitian dapat disimpulkan bahwa dalam pengelolaan dana desa, aspek kejelasan dan kelengkapan informasi yang diberikan oleh aparat pemerintah nagari Talaok telah memenuhi indikator transparansi sesuai dengan yang dikemukakan oleh Kristianten poin kedua tentang kejelasan dan kelengkapan informasi.

Kemudian aspek keterbukaan proses juga merupakan aspek penting terkait transparansi. Aspek keterbukaan dalam Kristianten (2006:45) menyebutkan bahwa transparansi adalah keterbukaan pemerintah dalam memberikan informasi yang terkait dengan aktifitas pengelolaan sumber daya publik kepada pihak yang membutuhkan, dalam hal ini yaitu masyarakat. 
Kemudian Kristianten (2006:31) juga mengemukakan bahwa transparansi juga akan memberikan dampak positif dalam tata pemerintahan. Transparansi akan meningkatkan pertanggungjawaban bagi para pencetus kebijakan sehingga kontrol masyarakat terhadap para pemegang otoritas pembuat kebijakan akan berjalan lebih efektif.

Dalam Permendagri No. 113 Tahun 2014, dijelaskan bentuk laporan pertanggungjawaban yang harus dibuat oleh pemerintah desa meliputi laporan semesteran pada bulan Juli dan akhir bulan Januari. Kemudian laporan pertanggungjawaban realisasi pelaksanaan APBDesa yang diserahkan paling lambat satu bulan setelah akhir tahun anggaran dengan melampirkan pertanggungjawaban realisasi dari pelaksanaan APBDesa bersangkutan, laporan kekayaan milik desa per 31 Desember, dan program pemerintah dan pemerintah daerah yang masuk ke desa.

Pemerintah Nagari Talaok telah menyatakan bahwa mereka sudah melakukan segala bentuk pertanggungjawaban sesuai dengan peraturan yang berlaku. Mulai dari laporan semesteran hingga laporan pertanggungjawaban realisasi pelaksanaan APBDesa beserta lampiran-lampiran yang harus dilampirkan sesuai dengan peraturan yang berlaku. Tetapi masih terdapat kendala dari kemampuan SDM aparatur Nagari Talaok yang akhirnya membuat laporan pertanggungjawaban nagari Talaok juga tidak tepat waktu sesuai dengan Permendagri No. 113 Tahun 2014.
Kendala-kendala yang dialami pemerintahan Nagari Talaok dalam transparansi penggunaan dana desa

Dalam transparansi penggunaan dana desa di Nagari Talaok Kecamatan Bayang Pesisir Selatan terdapat beberapa kendala yang dialami oleh pemerintahan Nagari Talaok. Pertama, kendala yang muncul berasal dari banyaknya usulan-usulan yang disampaikan oleh masyarakat nagari dalam musyawarah nagari mengenai rencana penggunaan dana desa. Usulan tersebut perlu disaring dahulu, dan yang paling penting baru dananya diprioritaskan untuk usulan tersebut. Tentunya usulan tersebut sudah disepakati oleh semua yang hadir dalam musyawarah nagari.

Kendala kedua yang dihadapi yaitu kualitas SDM atau lebih tepat mengenai kesiapan dari perangkat desa yang masih kurang. Kesiapan yang kurang akan memperlambat proses yang ada di pemerintah nagari. Akan tetapi, pemerintah nagari sudah memberikan pembinaan atau pendampingan kepada perangkat nagari agar bisa lebih maksimal dalam urusan ketanggapan dalam bekerja.

Ketiga, kendala yang di alami yaitu pemerintah nagari belum memiliki web, halaman facebook dan instagram sendiri. Sehingga untuk pelaporan penggunaan dana desa hanya melalui baliho yang dipampang di depan kantor wali nagari Talaok. Selain itu pelaporan dana desa dilakukan di mesjid dan di STIE. Karena pusat informasi tentang penggunaan dana desa hanya sedikit, masyarakat sulit memperoleh informasi. 


\section{SIMPULAN}

Pengelolaan dana desa yang diterapkan oleh pemerintah Nagari Talaok sudah sesuai dengan indikatorindikator transparansi yaitu kesediaan dan aksesibilitas dokumen, kejelasan dan kelengkapan informasi, keterbukaan proses, dan kerangka regulasi yang menjamin transparansi dan peraturan perundang-undangan maupun ketentuan-ketentuan yang berlaku. Disamping itu dalam prosesnya sudah melibatkan masyarakat mulai dari tahapan perencanaan sampai dengan pertanggungjawaban dan pengawasan. Dalam hal pelaporan dana desa yang dilakukan oleh pemerintah nagari sudah transparan melalui baliho, buku dan pelaporan di mesjid dan di STIE.

Pelaksanaan pertanggungjawaban dana desa oleh pemerintah Nagari Talaok secara teknis maupun administrasi sudah baik. Kendalakendala yang dialami pemerintahan nagari dalam transparansi penggunaan dana desa yaitu adanya aparatur nagari dalam menjalankan fungsinyanya masih kurang optimal. Ini dikarenakan terdapat beberapa faktor yang menjadikan kendala, yakni Sumber Daya Manusia (SDM), dan keterbatasan media dalam laporan penggunaan dana desa.

Pemerintah Nagari Talaok sudah melakukan dan menjalankan faktor transparansi dengan memasang baliho anggaran Alokasi Dana Desa di depan kantor wali nagari Talaok dan saran peneliti agar di setiap kampung / pos jaga juga di pasang baliho anggaran ADD sehingga mampu meningkatkan dukungan dan kepercayaan masyarakat terhadap aparatur nagari.

\section{DAFTAR PUSTAKA}

Krina L.P.L. 2003. Indikator dan Alat Ukur Prinsip Akuntabilitas, Transparansi dan Partisipasi. Jakarta: Badan Perencanaan Pembangunan Nasional.

Kristianten. 2006. Transparansi Anggaran Pemerintah. Jakarta : Rineka Cipta.

Undang-Undang Nomor 14 Tahun 2008 Tentang Keterbukaan Informasi Publik

Undang-Undang Nomor 32 tahun 2004 tentang Pemerintahan Daerah

Peraturan Menteri Dalam Negeri Nomor 113 tahun 2014 tentang pengelolaan Keuangan Desa

Undang-Undang Nomor 6 Tahun 2014

Peraturan Daerah Provinsi Sumatera Barat Nomor 2 Tahun 2007 Tentang Pokok-Pokok Pemerintahan Nagari 